\title{
PARAMETERS OF OPERATIONAL PERFORMANCE OF SOIL PREPARATION AND SEMI- MECHANIZED TRANSPLANTATION OF COFFEE SEEDLING
}

\author{
João P. B. Cunha ${ }^{1 *}$, Fabio M. da Silva², Ednilton T. Andrade², Murilo M. de Barros ${ }^{3}$
}

${ }^{1 *}$ Corresponding author. Universidade Federal Rural do Rio de Janeiro/ Seropédica - RJ, Brasil. E-mail: bcunha_2@hotmail.com

\section{KEYWORDS}

mechanization, planting seedlings, Coffea Arabica.

\begin{abstract}
In recent years, the coffee has undergone major changes, and in case of transplanting operation, the use of machinery has proved to be a viable alternative to producers. Prior knowledge of the influence of the variables that influence the operational capability of these machines can generate models to estimate precisely these parameters, thus enabling the optimization and management of mechanized operations. One of this tool is the use of the response surface methodology, which allows checking the influence of different independent variables and the response generated to allow a great value. This study aims to verify the use of the response surface method to determine parameters of mechanized operations in coffee plant implantation. The results show that the number of seedlings deposited increases with the increase in operating speed. In contrast, the adoption of higher speeds decreases the efficiency of the evaluated field operations. The response surface methodology was an important tool to check the effect of variables on performance parameters, and the generated models showed high significance allowing the identification of the effects of the operational speed and the average length of the cultivation line.
\end{abstract}

\section{INTRODUCTION}

The early planning in the implementation of a coffee plantations or any other culture has an important meaning and can guarantee the success of the activity. In this way, the mechanized transplanting operation was only feasible with the introduction of transplanting machines, allowing reductions in operating costs of up to $19 \%$ compared to the manual system (Cunha et al., 2015).

The coffee trees formed through the mechanized transplanting, associated to the uniformity in the positioning of the plants, act as an important factor for the production of the crop, influencing the quality and the productivity of the grains, as well as the cultural treatments and the mechanized harvest (Silva et al., 2014).

In the implantation of new crops, the use of conservation systems of soil preparation has improved the conditions for the crop development. Basically, in this type of system, the soil preparation is restricted to furrowing operations. Thus, after the furrow is opened, the fertilizer distribution and the incorporation into the soil through the pit beaters are carried out.
The mechanized planting or transplanting processes present very limited and/or old literature. In the case of crops such as sugarcane, vegetables and forest species, some studies have already been developed, except for coffee, in which studies are scarce.

One of the ways to understand the behavior of the mechanized set and the interaction of variables that affect its operational performance is the use of surface response models (SRM). According to Myers et al. (2009), the surface response methodology (SRM) is a collection of mathematical and statistical techniques that are used to model and analyze problems, in which the response of interest is influenced by many variables. The generated response must reach an optimal value and the form of relation between the response variable and the independent variables is unknown.

The surface models are often used in the substitution of complex models, in order to obtain a correlation between the experimental data, allowing to model more than one factor simultaneously and to test the interaction of the factors involved in the process, reducing the optimization problems, identifying optimal regions (Colaço et al., 2008).

\footnotetext{
${ }^{2}$ Universidade Federal de Lavras/ Lavras - MG, Brasil.

${ }^{3}$ Universidade Federal Rural do Rio de Janeiro/ Seropédica - RJ, Brasil.

Received in: 1-19-2018

Accepted in: 9-10-2018
} 
In general, the response surface methodology is widely used in different segments of the agrarian sciences, being little used for the study of performance parameters in mechanized operations. Based on the exposed, this study aims to verify the use of the response surface method to determine parameters of mechanized operations in the implantation of coffee crop.

\section{MATERIAL AND METHODS}

The experiment was conducted at the Conquista Farm belonging to the Ipanema Coffees' group, located in the municipality of Alfenas, Minas Gerais, in the 2013 and 2014 harvests, in soil predominantly classified as Red Distrophic Latosol. The data were collected in areas suitable for mechanization according to Silva \& Carvalho (2011), with fairly flat relief and slopes of up to $15 \%$, totaling thirty-five plots that served as a basis for modeling.

As a data base for the accomplishment of this study, we used the performance parameters of mechanized operations of the furrow preparation and transplantation of the coffee seedling. According to Figure 1a, in the furrow preparation, the Massey Ferguson tractor with $4 \times 2$ auxiliary front wheel drive (FWD), engine power of 55.0 $\mathrm{kW}(75 \mathrm{hp})$ at $2.000 \mathrm{rpm}$, was used in the $1 \mathrm{R}$ gear, obtaining average speed of $1.2 \mathrm{~km} \mathrm{~h}^{-1}$, which allowed to draw and to drive through the power take-off a pit beater from the Bertanha brand, with actuation width of $1.5 \mathrm{~m}$, so that the prepared furrows were realized in parallel in 3.8 $\mathrm{m}$, the desired planting spacing.

The transplanting operation was carried out inside the prepared furrows (Figure 1b), through a semimechanized platform, with capacity for 12 seedlings boxes, where the machine performs the furrow opening, and based on the rotation of the odometer wheel the seedling deposition, the subsequent furrow closure and soil compaction are carried out manually. As a source of power, the Massey Ferguson tractor, with 4x2 auxiliary front wheel drive (FWD), $55.0 \mathrm{~kW}$ (75 hp) engine power, was used at $1.500 \mathrm{rpm}$, operating in $2 \mathrm{R}$ gear, obtaining an average theoretical speed of $1.8 \mathrm{~km} \mathrm{~h}^{-1}$. In both mechanized operations, the slipping indices were within acceptable limits of up to $15 \%$ (Bowers, 1978).

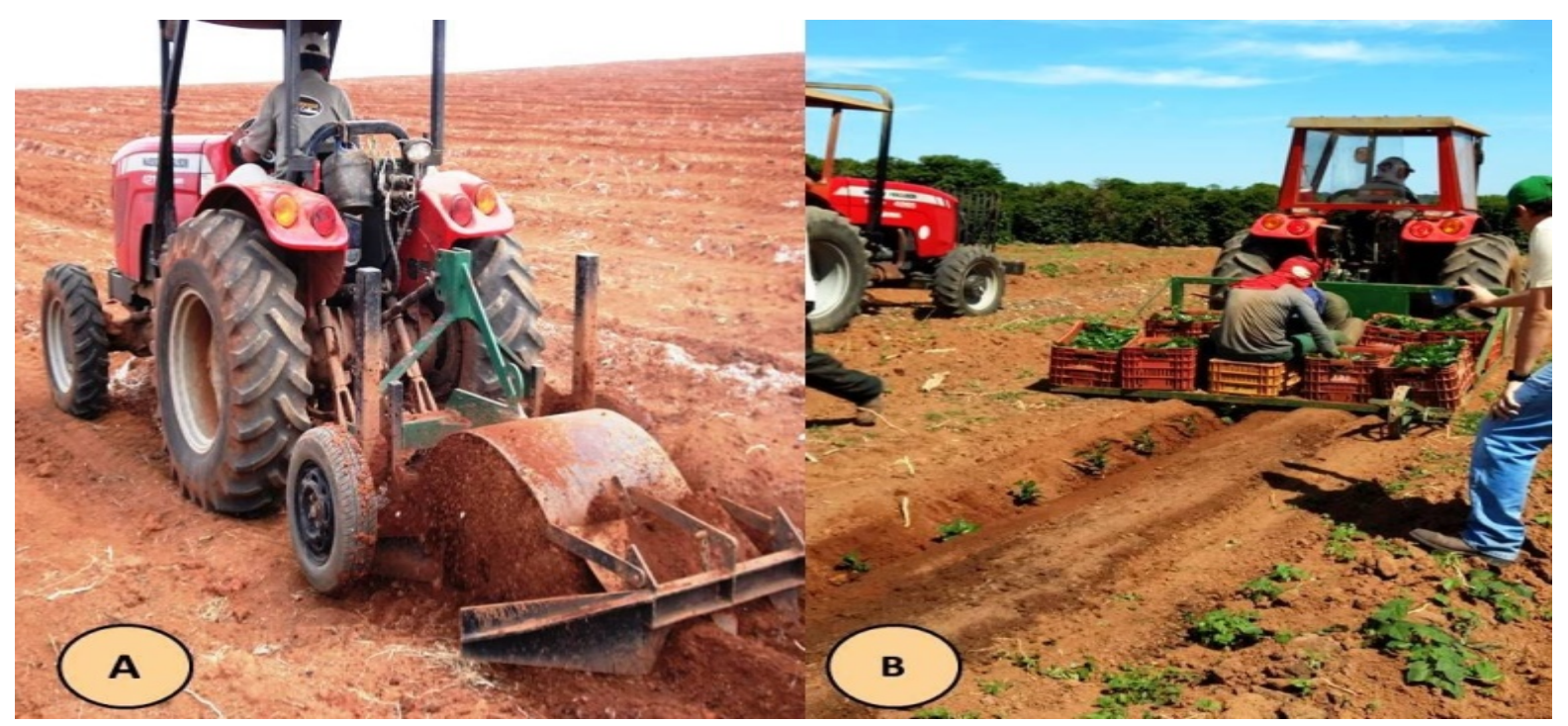

FIGURE 1. Furrow preparation and incorporation of fertilizers (A) and semi-mechanized transplanting operation of coffee seedling (B).

A Global Positioning System (GPS) receiver was used to obtain the total area of each plot, the lengths between the rows of the fields, the route and the operational speed of the machines. The data were collected and stored at a frequency of one data to each five seconds. Based on the data obtained by the receiver, the databases were generated and later stored and analyzed by the CR 7 Campeiro $^{\circledR}$ software, which allowed the subsequent achievement of performance parameters.

With all of this data, the performance parameters were calculated using an electronic spreadsheet. For the determination of the theoretical field capacity ( $\mathrm{TFc}$ ), the equation described by Vale et al. (2008) was used, which expresses the maximum work capacity demonstrated by the machine.

However, in the determination of effective field capacity $(\mathrm{EFc})$, a parameter that expresses the capacity effectively demonstrated by the machine in the field, the equation proposed by Simões \& Silva (2012) was used. In the case of the transplanting operation to determine the working capacity, the same equation was used, adapted for coffee cultivation, which allowed to express the machine's working capacity in number of plants per unit of time, according to [eq. (1)].

$$
\mathrm{EFc}=\left[\left(\frac{1 \mathrm{c}}{10000}\right) /\left(\frac{\mathrm{t}+\mathrm{tm}}{60}\right)\right] . \mathrm{Se}
$$

That:

EFc - Effective field capacity, plants ha'

1 - Useful working width of the implement, m;

c - Effective length of the interline, $\mathrm{m}$;

$\mathrm{t}$ - Machine operating time on the row, min;

tm- Time spent with the header maneuver, min,

Se - Plant effective stand, plants ha ${ }^{-1}$. 
Thus, the field efficiency (FE) was obtained by the ratio between the effective field capacities and the theoretical working capacity of the mechanized sets. In relation to the time demanded (Td), it expresses the time required to perform the operation in a given area, being determined according to the equation proposed by Brandão et al. (2013). In the case of the transplanting operation, the time demanded was obtained by the ratio of the theoretical stand to the desired spacing $(3.8 \times 0.7 \mathrm{~m})$, totaling 3,760 plants per hectare, and the effective field capacity $(\mathrm{EFc})$.

Based on the data obtained from each performance parameter in the mechanized operations studied, was chosen the model that best represented the characteristics of the variables under study, that is, operational speed, slope of the areas and average length of coffee rows.

The data used to generate the models were submitted to a previous analysis, verifying the presence of discrepant data, testing the homogeneity of variances and normality using the Shapiro-Wilk test at 5\% significance level. To determine the interaction of the analyzed factors, the Pearson correlation test was performed at $5 \%$ of significance, and it was later modeled using the response surface methodology (RSM).

The response surface methodology is a sequential procedure, in which most experiments begin with analyze of the linear models to verify the interaction of the factors. Thus, the generic models proposed for the variables responses to effective field capacity, field efficiency and time demanded are described in eqs (2) and (3).

$$
\begin{aligned}
& \mathrm{Zi}=\mathrm{Xi} \cdot \mathrm{a}+\mathrm{Yi} \cdot \mathrm{b}+\mathrm{c} \\
& \mathrm{Zi}=\frac{\mathrm{a}}{\mathrm{Xi}}+\frac{\mathrm{b}}{\mathrm{Yi}}+\mathrm{c}
\end{aligned}
$$

That:

\section{Z i- Performance parameter studied;}

$\mathrm{Xi}$ - Average length between the lines (m);

Yi - Operating speed $\left(\mathrm{km} \mathrm{h}^{-1}\right)$,

$\mathrm{a}, \mathrm{b}, \mathrm{c}$ - Coefficients of the equation.

The proposed models were generated by the STATISTICA $7.0^{\circledR}$ statistical program, and the regression study was carried out with first-level models using the adjustment procedure of non-linear models, with a 5\% significance level. After obtaining the proposed models, the estimators were determined, which allowed to verify the accuracy, precision and bias of each model generated.

The coefficient of determination $\left(\mathrm{R}^{2}\right)$ quantifies the quality of the adjustment, since it provides a measure of the variation proportion explained by the regression equation in relation to the total variation of the answers, varying from 0 to $100 \%$. Regarding the relative average error (p), it indicates the adjustment of the proposed model. In this study, the relative error was obtained according to [eq. (4)].

$$
\mathrm{p}=\frac{100}{\mathrm{n}} \Sigma \frac{|\mathrm{Y}-\mathrm{YO}|}{\mathrm{Y}}
$$

That:

$$
\begin{aligned}
& \mathrm{p} \text { - average relative error (\%); } \\
& \mathrm{n} \text { - number of experimental observations; } \\
& \mathrm{Y} \text { - observed value experimentally, } \\
& \mathrm{Y}_{\mathrm{o}} \text { - estimated value by the model. }
\end{aligned}
$$

The estimated average error of the models was obtained according to [eq. (5)], described by Reis et al. (2012). The estimated average error of a model indicates how much the estimated value of the model is far from the true average.

$$
S E=\sqrt{\frac{\Sigma\left(Y-Y_{0}\right)^{2}}{D F R}}
$$

That:

SE - estimated average error;

DFR - degree of freedom of the model;

$\mathrm{Y}$ - observed value experimentally,

$\mathrm{Y}_{\mathrm{o}}$ - estimated value by the model.

In relation to the chi-square test (x2), it compares the values observed in the sample with those predicted by the model, that is, it does not depend on the average and the variance, thus allowing to verify the dispersion of two variables, according to [eq. (6)].

$$
\mathrm{x}^{2}=\frac{\mathrm{E}(\mathrm{P}-\mathrm{Yo})^{2}}{\mathrm{DFR}}
$$

That:

$$
\begin{aligned}
& \mathrm{x}^{2}=\text { chi-square; } \\
& \text { DFR = degree of freedom of the model; } \\
& \mathrm{Y}=\text { observed value experimentally, } \\
& \mathrm{Y}_{\mathrm{o}}=\text { estimated value by the model. }
\end{aligned}
$$

\section{RESULTS AND DISCUSSION}

There was a significant correlation for the interaction of the cultivation line length and the operational speed, according to Table 1, where these parameters directly influence the performance of agricultural machines and their working capacity (Cunha et al., 2016). According to Figueiredo Filho \& Silva Junior (2009), the correlations obtained for the effective field capacity and time demanded were considered very strong, with values above $p=0.8$, when related to the operational speed factor, while presenting weak and moderate correlations for the average length of the cultivation line.

In the specific case of field efficiency, the behavior of the variables was different, that is, presented a moderate positive correlation, with values between $\mathrm{p}=0.4$ and 0.6 , for both operations for the length of the cultivation line and negative for the operating speed. Such behavior was already predicted since the field efficiency of the mechanized systems is related to times wasted in the process. 
TABLE 1. Correlation of operational performance parameters and cultivation line length and operational speed.

\begin{tabular}{lccc}
\hline Furrow preparation & $\mathrm{EFc}\left(\mathrm{ha} \mathrm{h}^{-1}\right)$ & $\mathrm{FE} \mathrm{( \% )}$ & $\mathrm{Td}\left(\mathrm{h} \mathrm{ha}^{-1}\right)$ \\
Length of line & $0.410^{*}$ & $0.641^{*}$ & $-0.421^{*}$ \\
Operational Speed & $0.991^{*}$ & $-0.353^{*}$ & $-0.948^{*}$ \\
\hline Transplanting & $\mathrm{EFc}\left(\mathrm{pls} \mathrm{h}^{-1}\right)$ & $\mathrm{FE} \mathrm{( \% )}$ & $\mathrm{Td}\left(\mathrm{h} \mathrm{ha}^{-1}\right)$ \\
Length of line & $0.467^{*}$ & $0.792^{*}$ & $-0.258^{*}$ \\
Operational Speed & $0.836^{*}$ & $-0.638^{*}$ & $-0.841^{*}$ \\
\hline
\end{tabular}

*Coefficient of Pearson correlation at 5\%, Effective field capacity (EFc), Field efficiency (FE), Time demanded (Td)

In the transplanting operation, for the field efficiency $(\mathrm{Ec})$, model 1 presented a better adjustment compared to the generic model 2, as in Table 2. According to Silva et al. (2007), the choice of the best model for the representation of the data passes through different criteria, especially the significance of the parameters and their coefficient of determination $\left(\mathrm{R}^{2}\right)$. On the other hand, for the field efficiency in the furrow preparation operation, model 2 presented better adjustment, as well as for the time demanded (Td).

TABLE 2. First level equations obtained for the parameters of operational performance as a function of the operational speed and average length of the lines.

\begin{tabular}{|c|c|c|c|c|c|c|c|}
\hline Furrow preparation & $\mathrm{a}$ & $\mathrm{b}$ & $\mathrm{c}$ & $\mathrm{R}^{2}$ & $p$ & $\mathrm{SE}$ & $x^{2}$ \\
\hline \multicolumn{8}{|l|}{$\operatorname{EFc}\left(\mathrm{ha} \mathrm{h}^{-1}\right)$} \\
\hline 1 & $0.00007^{*}$ & $0.2187^{*}$ & $0.0102 *$ & 99.32 & 0.57 & 0.041 & 0.001 \\
\hline 2 & $-1.414^{\mathrm{ns}}$ & $-0.274 *$ & $0.535 *$ & 92.07 & 2.61 & 0.025 & 0.002 \\
\hline \multicolumn{8}{|l|}{ FE $(\%)$} \\
\hline 1 & $0.0128 *$ & $-3.782 *$ & $64.92 *$ & 74.03 & 0.49 & 0.751 & 0.561 \\
\hline 2 & $-475.86^{*}$ & $3.252 *$ & $63.25 *$ & 98.79 & 0.11 & 0.161 & 0.026 \\
\hline \multicolumn{8}{|l|}{$\mathrm{Td}\left(\mathrm{h} \mathrm{ha}^{-1}\right)$} \\
\hline 1 & $-0.0012 *$ & $-2.904 *$ & $7.378 *$ & 91.85 & 2.62 & 0.215 & 0.046 \\
\hline 2 & $23.33 *$ & $4.005 *$ & - & 99.85 & 0.01 & 0.001 & 0.001 \\
\hline Transplanting & $\mathrm{a}$ & $\mathrm{b}$ & $\mathrm{c}$ & $2^{2}$ & $p$ & SE & \\
\hline \multicolumn{8}{|l|}{$\operatorname{EFc}\left(\mathrm{pls} \mathrm{h}^{-1}\right)$} \\
\hline 1 & $7.197^{*}$ & $796.01 *$ & $-225.3 *$ & 96.54 & 2.19 & 6.81 & 0.001 \\
\hline 2 & $-43740.1^{\mathrm{ns}}$ & $-1552.9 *$ & $3348.8 *$ & 89.33 & 3.85 & 120.11 & 0.004 \\
\hline \multicolumn{8}{|l|}{ FE $(\%)$} \\
\hline 1 & $0.241 *$ & $-12.48 *$ & $74.48 *$ & 97.94 & 0.84 & 1.22 & 0.001 \\
\hline 2 & $-1636.7 *$ & $17.66^{*}$ & $83.19 *$ & 97.02 & 1.05 & 1.46 & 0.002 \\
\hline \multicolumn{8}{|l|}{$\mathrm{Td}\left(\mathrm{h} \mathrm{ha}^{-1}\right)$} \\
\hline 1 & $-0.0065^{*}$ & $-1.193 *$ & $4.88^{*}$ & 80.12 & 5.76 & 0.25 & 0.062 \\
\hline 2 & $43.86^{*}$ & $2.631 *$ & - & 99.25 & 0.001 & 0.001 & 0.002 \\
\hline
\end{tabular}

Models 1$) z=a x+b y+c ; 2) z=(a / x)+(b / y)+c ;(a, b, c)$-parameters of the model; $\left(R^{2}\right)$ - Coefficient of determination; (p) - relative average error; (SE) - estimated average error; $\left(\mathrm{X}^{2}\right)$ - Chi-square; ${ }^{\text {ns }}$ - not significant and $*$ significant at $5 \%$ in the $\mathrm{F}$ test.

The estimated average errors (SE) and chi-square $\left(\mathrm{X}^{2}\right)$ of the chosen models presented values close to zero for all generated models. These results indicate that the models are adjusted. According to Molina Filho et al. (2006), the lower the value of these estimators is the smaller will be the discrepancy of the observed and obtained values by the model.

The relative error (p) of the models presented satisfactory values where, according to Mohapatra \& Rao (2005), values lower than $10 \%$ are recommended for the selection of models, for all performance parameters evaluated. According to Kashani-Nejad et al. (2007), the values of $p$ indicate the deviation of the values observed in relation to the curve estimated by the model and, therefore, there is no limitation of the use of the surfaces generated by the models proposed in this study.

Analyzing the effective field capacity (Figure 2), it is verified that the operational speed of the mechanized set is the one that most influences this parameter, a fact corroborated by the higher correlation obtained in the study. According to Ramos et al. (2012), the speed scaling, the relation between the working speed and the engine rotation allows a better adaptation of the tractor with the effort requested by the implement to carry out a certain work. 

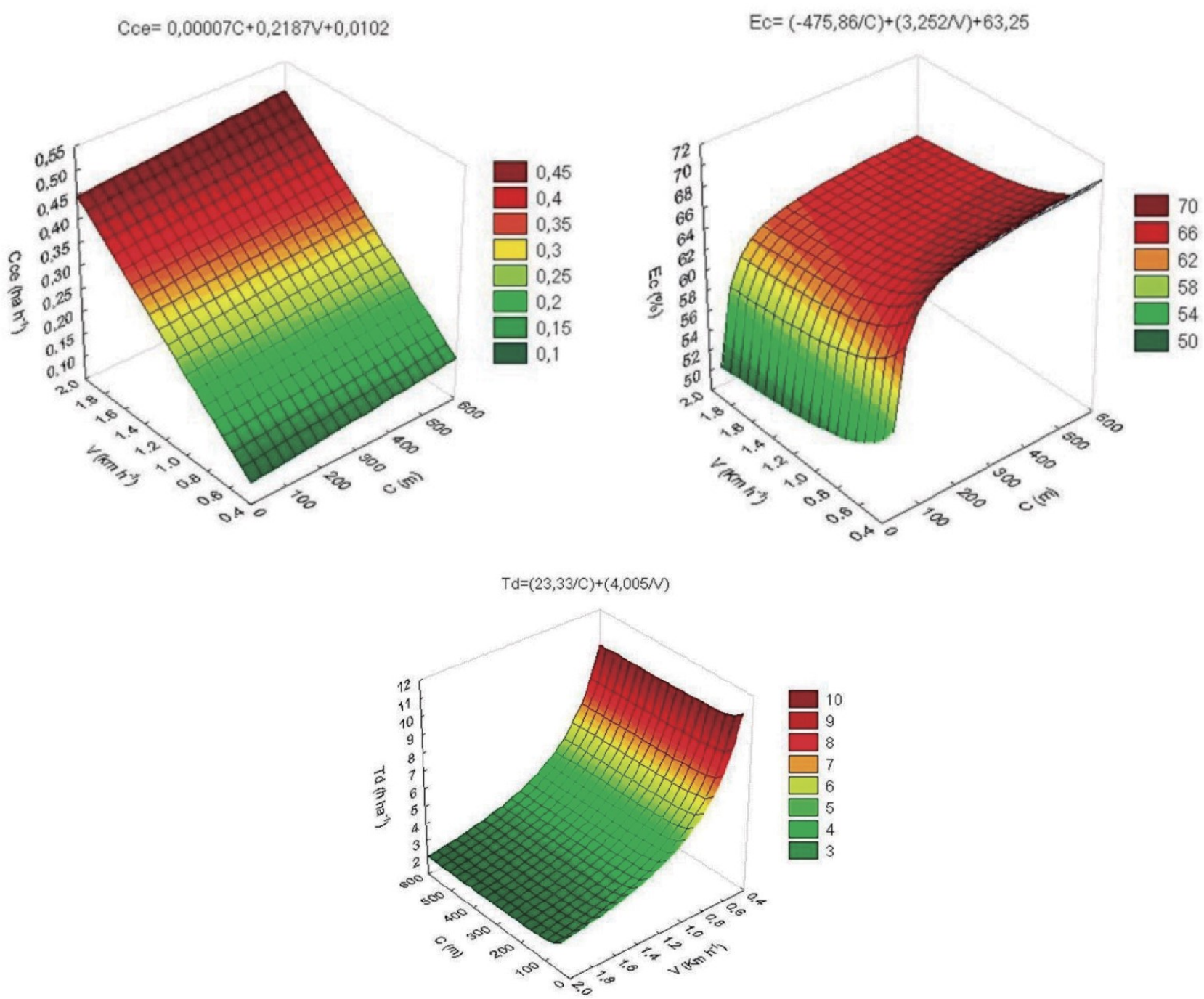

FIGURE 2. Response surfaces obtained for the furrow preparation operation.

By using a pit beater in the soil preparation, the comparison of the data obtained in this study with the literature, it is necessary with similar machines used in other studies. According to Mandal et al. (2015), the use of rotating soil preparation machines has been gaining space due to the high efficiencies obtained and simpler structures.

Silva et al. (2014) verified operational speeds varying between 1.5 and $2.2 \mathrm{~km} \mathrm{~h}^{-1}$ in the reduced soil preparation operation, values similar to those obtained in this study. Jakasiana et al. (2017), when evaluating the performance of a rotating grid in soil preparation in fallow or previously cultivated areas, verified average operating field capacities of $0.23 \mathrm{ha} \mathrm{h}^{-1}$ and values of up to $82.1 \%$ for field efficiency.

Carvalho Filho et al. (2007), using a rotary hoe machine with active organs similar to the equipment used in this study, add to the fact that the machine operating speed directly influences the greater disaggregation and greater soil pumping. These characteristics of preparation favor a greater area of exploration of the root system and, consequently, better development of the plants to be transplanted, mainly in more demanding crops (Sichocki et al., 2013).

According to Figure 2, the field efficiency decreases as the operating speed increases. This fact is expected, since, it is a performance parameter much more related to the necessary time of the set to carry out maneuvers and the time in operation. According to Cunha et al. (2016), plots with larger row lengths allow greater efficiencies due to the smaller proportion of wasted time with maneuvers in the total operation time. However, in Figure 2, it can also be observed that with row lengths from $250 \mathrm{~m}$, the efficiency varies minimally, tending to stabilize.

In relation to the semi-mechanized transplanting operation, it is observed in Figure 3 that the response surface for the field efficiency in the transplanting operation presents the same behavior as for the furrow preparation operation, where lower speeds combined with greater row lengths allow higher values to be obtained. 
The field efficiency can present great variation due to the fact that in the transplanting operation it is necessary to wait the mechanized set for the positioning of the support staff responsible for the manual transfer and verification of the process quality, which allows the identification of fallen seedlings, resulting in longer maneuvering times.

The time demanded for the transplanting operation is directly related to the working capacity of

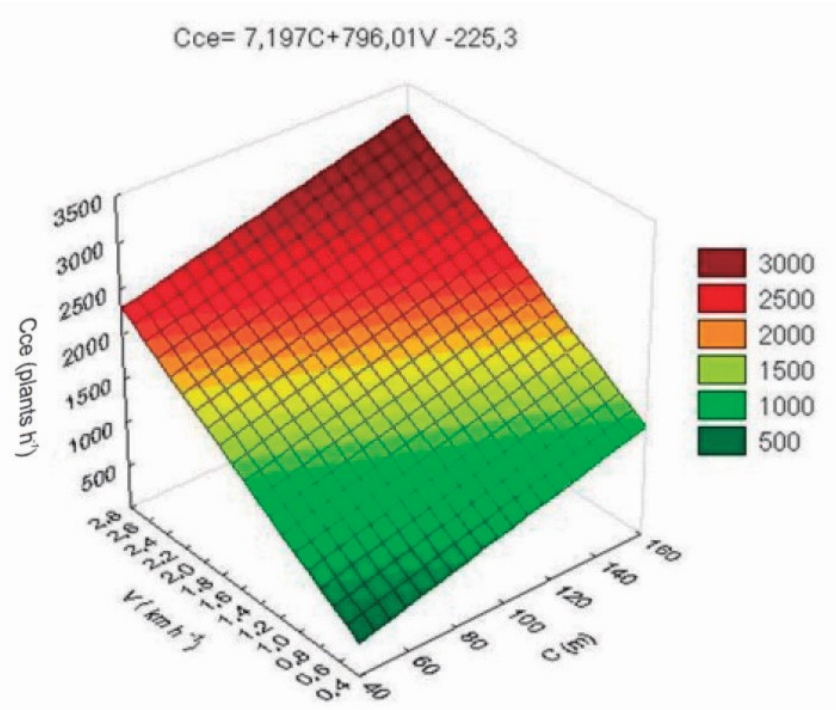

the set, that is, the number of plants deposited in the area. The data obtained in this study varied up to 7.5 hours for the time spent to transplant one hectare of coffee seedling, and as the operational speed of the set increases, the time demanded in the operation decreases. The result is within the expected since Cunha et al. (2015), analyzing different transplanting systems, found that with the equipment used in this study, an average of 3.5 hours of operation was spent to produce one hectare.
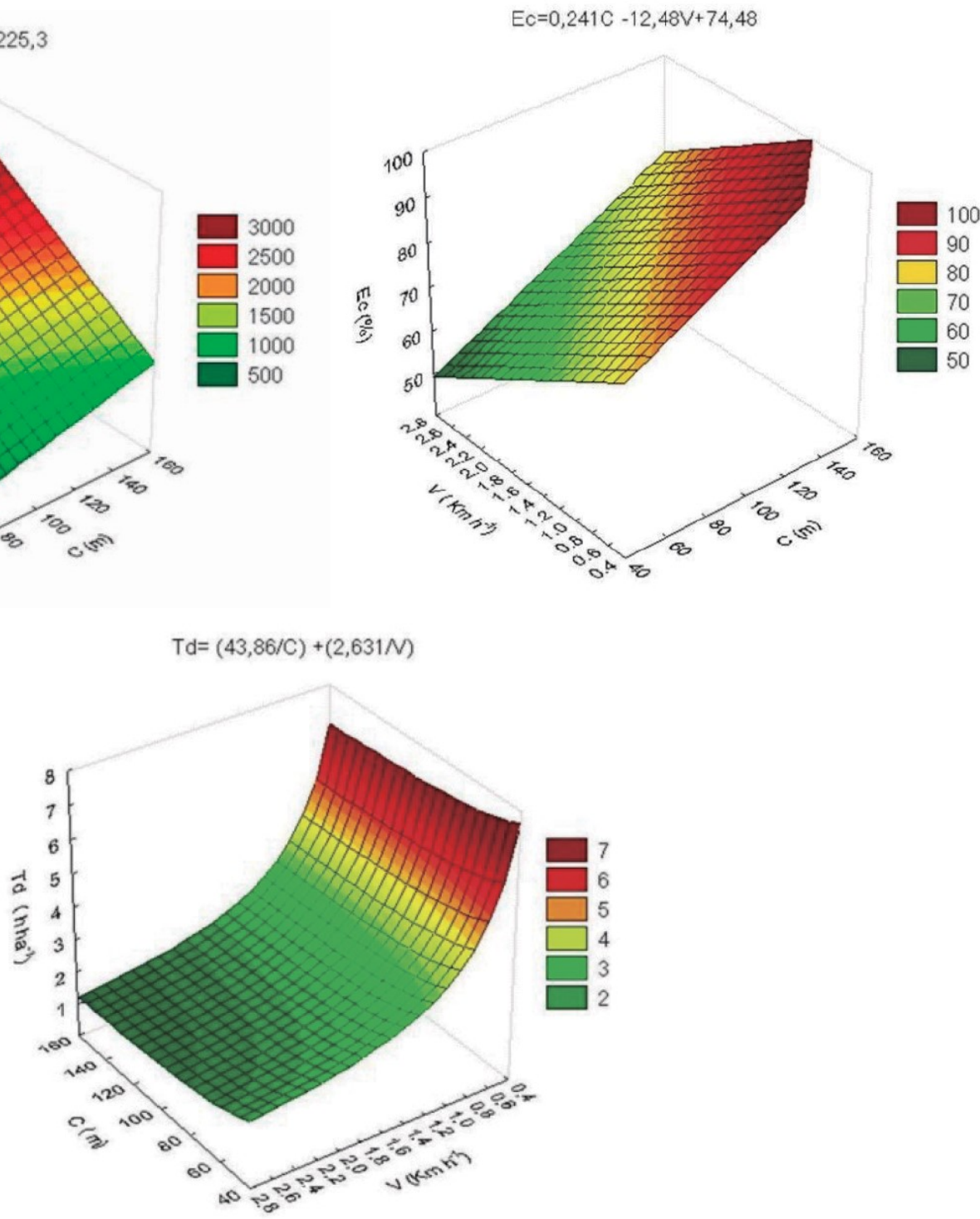

FIGURE 3. Response surfaces obtained for the transplanting operation.

The effective field capacity of the set increased according to the combined increase of the operating speed and the length of the planting line. Few studies on the process of semi-mechanized transplanting of coffee were carried out, being necessary the comparison with machines used in the transplanting of other crops and working in the same speed range, thus allowing a better understanding of the process.

Genaidy (2008), evaluating the operational capacity and productivity of a cotton transplanter, found that higher operating speeds reduced the overall field efficiency. Regarding the effective field capacity of the set, there was an increase of up to $68 \%$ when the speed increase occurred from 0.5 to $1.5 \mathrm{~km} \mathrm{~h}^{-1}$, speeds reached in this study.

According to Cunha et al. (2016), the speeds obtained in this study were among those considered ideal for the operation, allowing to say that possible variations in speed were obtained in function of soil conditions, the area slope, and machine ballasting. In contrast, it should be noted that high speeds may allow the reduction of the system efficiency, since, the distribution of plants is closely related to the speed of the set increasing the spacing as it increases (Cortez et al., 2006). 
Another problem related to speed increase is the deposition capacity of the seedlings in the soil due to the time required for the auxiliary planting to have sufficient time to deposit the seedlings in the machine deposition mechanism (Silva et al. 2014).

Based on the above, data about coffee transplanting are still poorly studied. Thus, for comparison in the case of transplanting of the industrial tomato, Machado et al. (2015), evaluating three different speeds of operation, concluded that the different speeds followed by passthrough modified the final stands in the studied processes, and the $1.83 \mathrm{~km} \mathrm{~h}^{-1}$ speed was more favorable with respect to the transplanted seedling stand and the $1.56 \mathrm{~km} \mathrm{~h}^{-1}$ speed, despite presenting a smaller number of plants ha $^{-1}$ showed tendencies for a better distribution uniformity.

Abidine et al. (2004) and Zamani (2014) mention that in addition to problems in the distribution of seedlings, the increase in operational speed can cause physical damage to the seedlings, thus reducing their viability. The increase in speed also modifies the depth and angle of the seedling deposition due to the limitations of the seedling deposition mechanisms of the transplanters evaluated.

According to Prasanna \& Raheman (2012), several studies are being carried out to ensure maximum operational efficiency of transplanting machines and improvements in deposition capacity with automated systems. Concomitant to these improvements, the use of surface response techniques to identify the influence of factors related to machine performance and the generation of optimum operating points may allow the obtainment of a greater technical feasibility of mechanized systems in the transplantation of coffee seedlings.

\section{CONCLUSIONS}

1. The response surface methodology was an important tool to observe the effect of the independent variables and their interaction allowing to verify the significant influence of the operational speed on the increase of the number of deposited plants and on the performance parameters of the mechanized sets.

2. The generated models presented high significance and allowed to identify satisfactorily the effects of the operational speed and length of the cultivation line, making possible the optimization in the use of the mechanized systems studied.

\section{REFERENCES}

Abidine AZ, Heidman BC, Upadhyaya SK, Hills DJ (2004) Autoguidance system operated at high speed causes almost no tomato damage. California Agriculture 58(1):44-47. Available in:

http://ucanr.edu/repository/a/?get=69099. Accessed: Mar 23, 2016.

Bowers W (1978) Matching equipment to big tractors for efficient field-operations. In: ASAE International Meeting, Utah, Utah State University. Procedings...

Brandão FJB, Silva ARB, Silva MAP, Sperotto FCS (2013) Desempenho operacional e produtividade agrícola do crambe nos preparos convencional e reduzido de solo. Enciclopédia Biosfera 9(17):3746-3756.
Carvalho Filho A, Centurion JF, Silva RP, Furlani CEA, Carvalho LCC (2007) Métodos de preparo do solo: alterações na rugosidade do solo. Engenharia Agrícola 27(1):229-237. DOI: http://dx.doi.org/10.1590/S010069162007000100017

Colaço JM, Dulikravich GS, Sahoo DA (2008) Response surface method-based hybrid optimizer. Inverse Problems in Science and Engineering 16(6):717-741. DOI: http://dx.doi.org/10.1080/17415970802082724

Cortez JW, Furlani CEA, Silva RP (2006) Semeadoras de precisão. Cultivar Máquinas (56):16-19.

Cunha JPB, Silva FM, Andrade F, Machado TA, Batista FA (2015) Análise técnica e econômica de diferentes sistemas de transplantio de café (coffea arabica 1.). Coffee Science 10(3):289-297.

Cunha JPB, Silva FM, Dias REBA (2016) Eficiência de campo em diferentes operações mecanizadas na cafeicultura. Coffee Science 11(1):76-86.

Figueiredo Filho DB, Silva Júnior JA (2009) Desvendando os mistérios do coeficiente de correlação de Pearson (r). Revista Política Hoje 18(1):115-46.

Genaidy MAI (2008) Performance of small cotton transplanter under Egyptian conditions. Misr Journal of Agricultural Engineering 25(1):1-14.

Jakasiana RG, Vadher AL, Kathiria RK (2017) Performance Evaluation of Vertical Rotary Plough. Journal of Scientific Research \& Reports 13(6):1-7.

Kashani-Nejad MA, Mortazavi A, Safekordi AG, Tabil LG (2007) Thin-layer drying characteristics and modeling of pistachio nuts. Journal of Food Engineering 78(1):98-108. DOI: http://dx.doi.org/10.1016/j.jfoodeng.2005.09.007

Machado TA, Santos FL, Valente DSM, Fernandes HC, Cunha JPB (2015) Transplantio semi-mecanizado de mudas de tomate em função da velocidade de operação. Revista Agroambiente 9(1): 48-56. DOI: http://dx.doi.org/10.18227/1982-8470ragro.v9i1.1859

Mandal S, Bhattacharyya B, Mukherjee S (2015) Design of Rotary Tiller's Blade Using Specific Work Method (SWM). Journal of Applied Mechanical Engineering 4(3):1-6. DOI: http://dx.doi.org/10.4172/21689873.1000164

Molina Filho L, Pedro MAM, Romero JT, Barboza SHR (2006) Influência da temperatura e da concentração do cloreto de sódio $(\mathrm{NaCl})$ nas isotermas de sorção da carne de tambaqui (Colossoma macroparum). Ciência e Tecnologia de Alimentos 26(2): 453-458. DOI: http://dx.doi.org/10.1590/S0101-20612006000200032

Mohapatra D, Rao PSA (2005) Thin layer drying model of parboiled wheat. Journal of Food Engineering 66:513-518. DOI: http://dx.doi.org/10.1016/j.jfoodeng.2004.04.023

Myers RH, Montgomery DC, Cook CMA (2009) Response surface methodology: process and product optimization using design of experiments. Willey, 704p.

Prasanna KGV, Raheman H (2012) Automatic feeding mechanism of a vegetable transplanter. International Journal of Agriculture and Biological Engineering 5(2):2027. Available in: https://ijabe.org/index.php/ijabe/article/view/525. Accessed: Nov 18, 2017. 
Ramos CR, Lanças KP, Masiero FC, Lyra GA, Marasca I

(2012) Potência e economia. Cultivar Máquinas (11):28-31.

Reis RC, Devilla IA, Ascheri DPR, Servulo ACO, Souza AB (2012) Cinética de secagem em folhas de manjericão (Ocimum basilicum L.) via infravermelho. Revista Brasileira de Engenharia Agrícola e Ambiental 16(12):1346-1352. DOI: http://dx.doi.org/10.1590/S141543662012001200012

Sichocki D, Ruas RAA, Dezordi, LR, Caixeta LF, Silva BM (2013) Consumo energético e patinagem de um trator agrícola tracionando uma enxada rotativa e um arado de discos. Engenharia na Agricultura 21(5):441-446.

Silva FM da, Carvalho GR (2011) Evolução da mecanização na cafeicultura. Informe Agropecuário 32:52-65.

Silva RP, Voltarelli MA, Cassia MT, Vidal DO, Cavichioli FA (2014) Qualidade das operações de preparo reduzido do solo e transplantio mecanizado de mudas de café. Coffee Science 9(1):51-60.
Silva MCC, Fontes PCR, Miranda GV (2007) Modelos estatísticos para descrever a produtividade de batata em função da adubação nitrogenada. Horticultura Brasileira 25(3):360- 364. DOI: http://dx.doi.org/10.1590/S010205362007000300008

Simões D, Silva MR (2012) Desempenho operacional e custos de um trator de irrigação pós-plantio de eucalipto em campo. Revista Ceres 59(2): 164-170. DOI: http://dx.doi.org/10.1590/S0034-737X2012000200003

Vale WG, Garcia RF, Thiebaut JTL, Amim RT, Tourino MCC (2008) Desempenho e dimensionamento amostral para a avaliação de uma semeadora-adubadora em plantio direto e convencional. Acta Scientiarium Agronomy 30(4):441-448. DOI:

http://dx.doi.org/10.4025/actasciagron.v30i4.5295

Zamani DM (2014) Development and evaluation of a vegetable transplanter. International Journal of Technical Research and Applications 2(6):40-46. Available in: http://www.ijtra.com/special-issue-view/development-andevaluation-of-a-vegetable-transplanter.pdf. Accessed: Oct 23, 2017. 